Огляди літератури, оригінальні дослідження, погляд на проблему, випадок з практики, короткі повідомлення УДК 616.441-008.61:616.391:[577.161.2+546.15]-055.2

DOI 10.11603/1811-2471.2020.v.i4.11770

\title{
ОЦІНКА РІВНЯ ВІТАМІНУ D I ЙОДНОГО СТАТУСУ В ЖІНОК ПРЕМЕНОПАУЗАЛЬНОГО ВІКУ 3 АВТОІМУННИМ ЗАХВОРЮВАННЯМ ЩИТОПОДІБНОї ЗАЛОЗИ
}

\author{
๑О. О. Чукур, Н. В. Пасєчко, А. О. Боб
}

Тернопільський національний медичний університет імені І. Я. Горбачевського МОЗ Украӥни

PEЗЮМЕ. У жінок пременопаузального віку з гіпотиреозом автоімунного ґенезу спостерігаються дефіцит вітаміну D та недостатнє йодне забезпечення.

Мета роботи - визначити рівень забезпеченості вітаміном 25(OH)D3 та провести оцінку медіани йодурії у жінок пременопаузального віку з автоімунним гіпотиреозом.

Матеріал і методи. Обстежено 146 жінок пременопаузального віку з гіпотиреозом на тлі автоімунного тиреоїдиту. Для оцінки функціонального стану щитоподібної залози визначали рівень тиреотропного гормону, вільного тироксину, вільного трийодтироніну та рівень антитіл до тиреопероксидази і антитіл до тиреоглобуліну. Визначали рівень вітаміну D у сироватці крові в осінньо-зимовий період та оцінювали йодне забезпечення за концентрацією йоду в разових порціях сечі.

Результати. У жінок пременопаузального віку з автоімунним гіпотиреозом у 78,8 \% визначався дефіцит, і у $17,1 \%$ - нестача вітаміну D. Результати визначення медіани йодурії показали недостатнє йодне забезпечення у 48,9 \% хворих (легкий дефіцит йоду у 26,7 \% і середнього ступеня тяжкості у 22,2 \%) та надмірне йодне навантаження у 8,9 \% хворих. Встановлено достовірно сильні негативні кореляційні взаємозв'язки між 25(OH)D та рівнем антитіл до тиреопероксидази і тиреотропним гормоном та середню позитивну кореляцію із рівнем вільного тироксину і вільного трийодтироніну $(p<0,05)$. Кореляційний аналіз визначив позитивні взаємозв'язки середньої сили між рівнем медіани екскреції йоду з рівнями тиреотропного гормону та антитіл до тиреопероксидази $(p<0,05)$.

Висновок. Дефіцит вітаміну D корелює зі зниженням функції щитоподібної залози та тяжкістю гіпотиреозу, що визначає необхідність додаткового призначення вітаміну D всім жінкам пременопаузального віку з автоімунним гіпотиреозом. Для контролю йодного статусу жінок з гіпотиреозом автоімунного ґенезу необхідно проводити моніторинг функції щитоподібної залози та концентрації йоду в організмі.

КлючОВІ СЛОВА: щитоподібна залоза; гіпотиреоз; автоімунний тиреоїдит; постменопаузальний вік; вітамін D; йодурія; йододефіцит.

Вступ. У структурі тиреоїдної патології автоімунні захворювання (АІЗ) щитоподібної залози (ЩЗ) займають одне з провідних місць [1]. Висока частота захворювань ЩЗ в Україні залежить від багатьох причин, серед яких основними причинами $\epsilon$ недостатність йоду в харчуванні населення, незбалансованість мікроелементного і вітамінного складу в раціоні харчування на тлі погіршення екологічної ситуації та недостатньої ефективності профілактичних заходів [2]. ЩЗ $\epsilon$ найчутливішим органом до автоімунних процесів унаслідок негативного впливу екзо- та ендогенних чинників на тлі генетичної схильності.

Гострою проблемою залишається профілактика та лікування йододефіцитних захворювань (ЙДЗ) Щ3, таких як ендемічний зоб, дифузний токсичний зоб, хронічний автоімунний тиреоїдит. Аналіз літератури показав, що ЙДЗ можуть бути наслідком не тільки недостатнього надходження йоду до організму, а й результатом дефіциту взаємозв'язаних з ним мікроелементів. Найпоширенішим струмогенним фактором $\epsilon$ дефіцит йоду та дисбаланс ряду мікроелементів - селену, заліза, цинку, кальцію, кобальту, міді, ртуті, марганцю, свинцю тощо [3]. Вони можуть потенційно впливати на дефіцит йоду або перешкоджати його засво$\epsilon$ нню ЩЗ за умов нормального його вживання. Не тільки нестача, а й надлишок йоду може спричинити виникнення автоімунних захворювань (AI3) щЗ [4]. Світові зусилля в напрямку запобігання йододефіциту за допомогою добавок йоду, такі як загальне йодування солі, досягли вражаючих успіхів за останні кілька десятиліть.

Відома роль вітаміну D в обміні кальцію і кісткового метаболізму, також підтверджено нескелетні ефекти значимості вітаміну D для різних органів і систем, виявлено взаємозв'язок між його дефіцитом і різними метаболічними порушеннями, захворюваннями серцево-судинної, ендокринної, імунної, репродуктивної та інших систем [5]. Встановлено, що дефіцит вітаміну D корелює зі збільшенням захворюваності на AІ3, включаючи цукровий діабет 1-го типу, ревматоїдний артрит, системний червоний вовчак, розсіяний склероз та хворобу Крона $[6,7]$. Однак незрозуміло, чи низький рівень вітаміну D тісно корелює з розвитком Al3 щ3. Останні епідеміологічні дослідження свідчать про зв'язок між Al3 щЗ та дефіцитом вітаміну D [8]. Крім того, взаємозв'язок низького рівня вітаміну D з більшою поширеністю $\mathrm{Al} 3 \epsilon$ значно більшим у жінок в пременопаузі, ніж у жінок у постменопаузальному віці [9].

Враховуючи багатофакторність розвитку, значну поширеність гіпотиреозу (ГТ), зумовленого ав- 
Огляди літератури, оригінальні дослідження, погляд на проблему, випадок з практики, короткі повідомлення тоімунним ураженням ЩЗ, в Україні, та відсутність чітких рекомендацій щодо ефективних заходів профілактики, існує необхідність у детальнішому вивченні факторів ризику виникнення вказаної патології у жінок репродуктивного віку.

Мета - визначити рівень забезпеченості вітаміном 25(OH)D та провести оцінку медіани йодурії у жінок пременопаузального віку з автоімунним гіпотиреозом.

Матеріал і методи дослідження. Обстежено 146 жінок з ГТ на тлі автоімунного тиреоїдиту (AIT). У дослідження були включені жінки пременопаузального віку (від 40 до 54 років (пік первинного виявлення гіпотиреозу)) середній вік склав $(43,8 \pm 0,7)$ років, статус менопаузи визначали за допомогою самозвітної анкети про менструальні кровотечі та їх регулярність. Тривалість захворювання склала $(6,4 \pm 1,7)$ (від 3 до 8) років. Обстежувані перебували на амбулаторному та стаціонарному лікуванні у відділенні ендокринології та ендокринологічному диспансері університетської лікарні Тернополя. 3 дослідження виключали пацієнток, які мали супутні хронічні соматичні захворювання з тяжким чи прогресуючим перебігом. Усі пацієнти підписували інформовану згоду на участь у дослідженні. Після отримання висновку етичної комісії при Тернопільському національному медичному університеті імені І. Я. Горбачевського проводили дослідження із дотриманням усіх морально-етичних принципів із урахуванням Гельсінської декларації Всесвітньої медичної асоціації 3 біомедичнихдосліджень (World Medical Association Declaration of Helsinki).

Для оцінки функціонального стану щЗ визначали рівні тиреотропного гормону (ТТГ), вільного

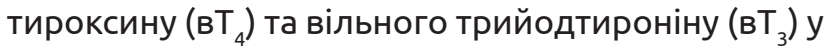
сироватці крові за допомогою електрохемілюмінесцентного методу на автоматичному аналізатоpi Roche «Cobas-411" із використанням реактивів компанії Roshe Diagnostics (Germany). Дослідження рівня антитіл до тиреопероксидази (АТПО) та антитіл до тиреоглобуліну (АТТГ) проводили за допомогою наборів Orgentec GmbH (Germany). Діагноз автоімунного тиреоїдиту (AIT) встановлювали при підвищенні показників АТПО та/або АТТГ та наявності характерної ультрасонографічної картини щз.

Для визначення рівня 25(OH)D у сироватці крові, яке проводилось в осінньо-зимовий період, використовували електрохемілюмінесцентний метод за допомогою апарата Elecsys 2010 (Roche Diagnostics, Germany), при цьому використовували набір 25-OH Vitamin D ELISA (EUROIMMUN, Germany).

Визначення концентрації йоду проводили у разових порціях сечі за допомогою церій-арсеніт-

ного методу Sandell-Koltoff у модифікації Dunn у лабораторії епідеміології ендокринних захворювань Інституту ендокринології та обміну речовин імені В. П. Комісаренка АМН України, що входить до Міжнародної програми EQUIP та постійно проходить зовнішній контроль якості в центрі CDC, Атланта.

Статистичну обробку результатів та візуалізацію отриманих результатів здійснювали із застосуванням пакета програм для статистичного аналізу STATISTICA 12. Для оцінки ступеня взаємозв'язку проводили кореляційний аналіз із розрахунком лінійного коефіцієнта кореляції (г) та його достовірності (р). Метод Пірсона вважають найточнішим для вивчення кореляції, оскільки одночасно отримуємо інформацію про напрямок взаємодії (пряма +, зворотна -) та силу зв'язку (від 0 до 1). Якщо г=0 вважають, що зв'язок відсутній, проміжок 0-0,3 вказує на слабку кореляцію, інтервал 0,3-0,7 свідчить про асоціацію середньої сили, а відрізок від 0,7 до 1,0 - про сильний зв'язок. Значимість відмінностей між величинами вважали достовірними при $\mathrm{p}<0,05$.

Результати й обговорення. Діагноз ГТ ґрунтувався на характерних клінічних симптомах, результатах лабораторно-інструментального дослідження. Ми оцінювали функціональний стан щЗ у жінок, хворих на ГТ автоімунного ґенезу. Середній рівень ТТГ у них становив $(4,44 \pm 0,21)$ мМо/мл; в $\mathrm{T}_{3}-$ $(1,97 \pm 0,09)$ нмоль/л; вТ 4 - $(12,96 \pm 0,37)$ пмоль/л; АТПО - $(112,87 \pm 5,61)$ Мо/мл; АТТГ - $(152,25 \pm$ $5,04)$ Мо/мл, p<0,05. Для компенсації ГТ хворі отримували левотироксин натрію в замісних дозах, які становили від 50 до 150 мкг. Відповідно до рівнів ТТГ компенсований ГТ виявлено у 94 жінок (64,4 \%), субкомпенсований - у 52 (35,6 \%).

Оцінку статусу вітаміну D проводили за рекомендаціями Міжнародного товариства ендокринологів, згідно з якими дефіцит вітаміну D встановлюється при рівні 25(OH)D нижче 20 нг/мл, нестача вітаміну D - як рівень 25(OH)D в межах 20-30 нг/мл і нормальний вміст при рівні 25(OH)D вище 30 нг/мл. Середній рівень 25(OH)D у жінок з ГТ (рис. 1), які включені у дослідження, склав $(16,42 \pm 0,57)$ нг/мл, що відповідає дефіциту вітаміну D (<20 нг/мл). У 115 (78,8 \%) жінок виявлено дефіцит вітаміну D, середній рівень $25(\mathrm{OH})$ D становив $(13,81 \pm 0,37)$ нг/мл, ( $p<0,005)$. У 25 (17,1 \%) хворих спостерігалась нестача вітаміну D з середнім значенням 25(OH)D $(23,02 \pm 0,54)$ нг/мл, 6 жінок $(4,1 \%)$ мали достатній рівень вітаміну D, середнє значення 25(OH)D становило $(39,02 \pm 1,91)$ нг/мл $(p<0,05)$. Наші результати збігаються з попередніми дослідженнями, які показали, що частота дефіциту та нестачі вітаміну D у хворих на Al3 щЗ є значно вищою, ніж у здоровій популяції $[10,11]$. 
Огляди літератури, оригінальні дослідження, погляд на проблему, випадок з практики, короткі повідомлення

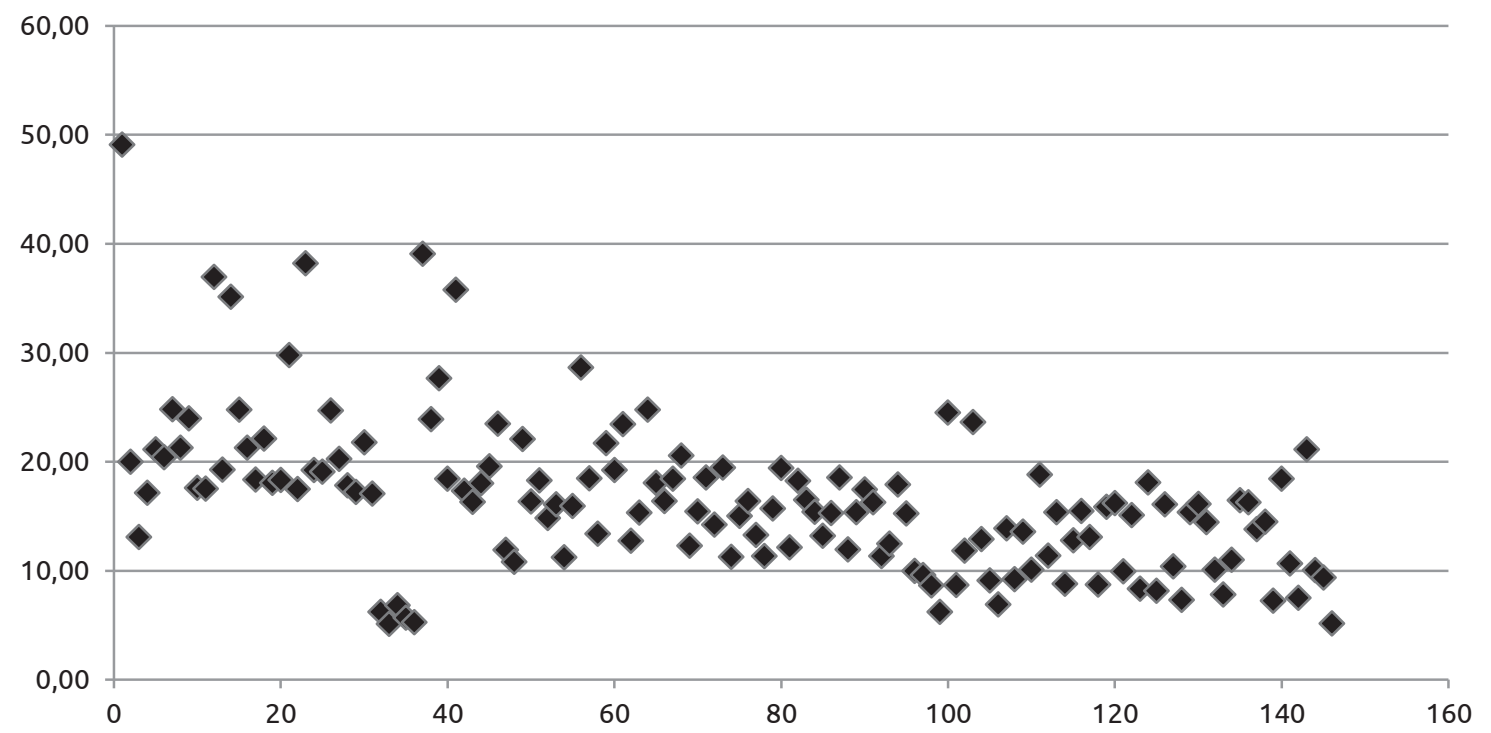

Рис. 1. Рівень забезпеченості вітаміном D у сироватці крові у жінок пременопаузального віку з гіпотиреозом автоімунного генезу.

Проведений кореляційний аналіз за методом Пірсона визначив взаємозв'язки між рівнем вітаміну D та рівнем тиреоїдних гормонів, ТТГ, АТПО, АТTГ. Відзначався достовірно сильний негативний кореляційний зв'язок між 25(OH)D з АTПО $(r=-0,77)$ і рівнем ТТГ $(r=-0,72)$ та негативний середньої сили - з АТТГ (r=-0,33), $p<0,05$. Позитивні кореляції середньої сили були встановлені з рівнем вТ $(r=0,46)$ та вT $(r=0,44) p<0,05$. Наші результати свідчать, що дефіцит вітаміну D також корелює із зниженням функції ЩЗ та наявністю АТПО і АТТГ. Аналогічні результати отримані дослідниками Поворознюк В. В, Паньків І. В., які виявили підвищення частоти дефіциту вітаміну D серед хворих з автоімунною патологією ЩЗ, особливо з автоімунним тиреоїдитом [12].

У дослідженні Choon-Young Kim et al. [13] було встановлено, що низький статус вітаміну D був суттєво пов'язаний із автоімунною дисфункцією ЩЗ, особливо у жінок пременопаузального віку. Dohee Kim [14] у своїх дослідженнях вивчав взаємозв'язок недостатності вітаміну D з Al3 Щ3, зокрема ГT, і повідомив, що нижчі рівні $25(\mathrm{OH})$ D у сироватці крові були пов'язані з вищим рівнем ТТГ.

Йод - важливий мікроелемент, який необхідний для функціонування ЩЗ та синтезу тиреоїдних гормонів. Найінформативнішим біохімічним показником споживання йоду $\epsilon$ визначення медіани йодурії, рівень якої відображає адекватність надходження цього мікроелемента в організм на момент вимірювання. Згідно із зазначеними епідеміологічними критеріями, при медіані йодурії менше ніж 20 мкг/л споживання йоду вважають недостатнім, а дефіцит йоду тяжким; при медіані йодурії 20-49 мкг/л споживання йоду вважають недостатнім, а дефіцит йоду помірним; при медіані йодурії 50-99 мкг/л споживання йоду вважають недостатнім, а дефіцит йоду слабким. При цьому, якщо медіана концентрації йоду в сечі перевищує 100 мкг/л, то це свідчить про відсутність дефіциту йоду. При медіані йодурії 100-199 мкг/л споживання йоду вважають нормальним та забезпечення ним оптимальним; при медіані йодурії 200299 мкг/л споживання йоду вважають більшим за потрібне, а забезпечення йодом може створити незначний ризик надмірного споживання; при медіані йодурії 300 мкг/л або більше споживання йоду вважають надмірним, існує небезпека негативних наслідків для здоров'я [15].

Визначення концентрації йоду проводили у разових порціях сечі 90 жінок, хворих на ГТ автоімунного генезу в стані компенсації, середній рівень ТТГ становив $(2,95 \pm 0,14)$ мМо/мл, $(p<0,005)$. Проведений аналіз частотного розподілу концентрації йоду в сечі в обстежених жінок показав, що у $48,9 \%$ хворих медіана йодурії становила в середньому 56,52 (96,51-24,64) мкг/л, що свідчить про недостатнє йодне забезпечення. Легкий дефіцит йоду був виявлений у $26,7 \%$, середнього ступеня тяжкості у 22,2 \% жінок (рис. 2). Оптимальне забезпечення йодом спостерігалось у 35,5 \% жінок із діапазоном коливань медіани рівня екскреції йоду від 186,95 до 121,26 мкг/л. У 6,7 \% обстежених жінок медіана йодурії коливалась від 271,22 до 225,94 мкг/л, що свідчить про незначний ризик надмірного споживання йоду. У 8,9\% жінок діапазон коливань медіани йодурії становив від 328,25 до 410,24 мкг/л, що свідчить про небезпеку нега- 
Огляди літератури, оригінальні дослідження, погляд на проблему, випадок з практики, короткі повідомлення

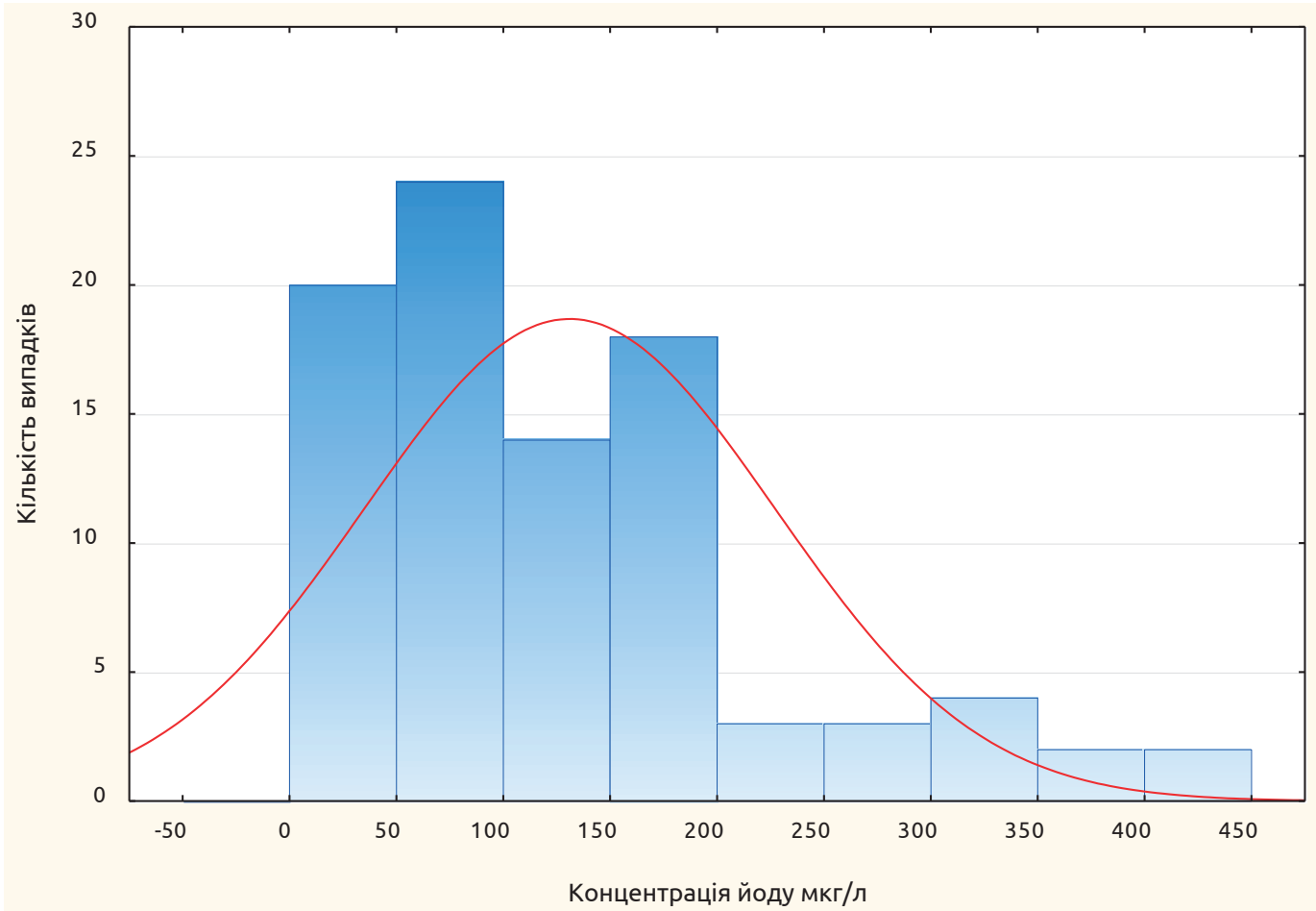

Рис. 2. Гістограма частоти випадків гіпотиреозу автоімунного ґенезу в жінок пременопаузального віку залежно від концентрації йоду в сечі.

тивних наслідків для здоров'я. Результати визначення медіани йодурії у жінок пременопаузального віку з ГТ автоімунного генезу показали недостатнє йодне забезпечення у половини хворих 48,9 \% (легкий дефіцит йоду в 26,7 \%, нестача середнього ступеня тяжкості - у 22,2 \%) та надмірне йодне навантаження у 8,9 \% обстежених. Наші дані збігаються з науковими працями інших науковців, які показали, що нестача йоду у хворих на Al3 щ3 трапляється значно частіше, ніж у здоровій популяції [16].

Результати наших досліджень свідчать, що у 8,9 \% жінок пременопаузального віку, хворих на ГТ автоімунного ґенезу, спостерігалося надмірне йодне навантаження, що збігається з даними інших дослідників, які зафіксували таку ж низку змін [17]. Як не дивно, але саме надмірна кількість йоду в зовнішньому середовищі (воді, ґрунті, повітрі, продуктах харчування) частіше поєднується з розвитком автоімунного ГТ, підвищеними рівнями антитиреоїдних антитіл, ніж нестача йоду. Існує більше доказів зв'язку розвитку автоімунного тиреоїдиту з надлишком йоду, ніж з дефіцитом, особливо у генетично сприйнятливих осіб.

Проведений нами кореляційний аналіз визначив позитивні взаємозв'язки середньої сили між рівнем медіани рівня екскреції йоду з рівнем ТТГ $(r=0,24)$, АТПО $(r=0,21)$ і слабкої сили - з АТТГ $(r=0,14)$ p<0,05. Аналіз літератури свідчить, що циркулюючі АТПО та АТТГ поширені як у популя- ціях із стабільно високим споживанням йоду, так і у тих, хто має легкий та помірний дефіцит йоду. Однак, надмірне споживання препаратів йоду в людей у йододефіцитному регіоні також створює підвищений ризик AІ3 Щ3, що підтверджують дослідження в багатьох країнах $[18,19]$.

На сьогодні йододефіцит у всьому світі суттєво зменшився завдяки впровадженню в багатьох країнах програм обов'язкового збагачення продуктів харчування йодом. Ці зусилля привели до викорінення тяжкого йододефіциту, проте паралельно це призвело й до збільшення поширеності AІ3 Щ3 [20]. Оскільки в Україні не запроваджена загальнонаціональна програма подолання йододефіциту, проблема профілактики йодозалежних захворювань загалом залишається не вирішеною. Впровадження йодної профілактики є нагальним завданням, що дозволить не тільки усунути низку проявів тиреоїдної патології, а й значно покращить здоров'я населення. Відсутність чітких критеріїв контролю індивідуальної профілактики в окремих випадках призводить до надмірного надходження йоду в організм, що зумовлює ризик виникнення AІ3 ЩЗ у здорового населення та погіршує перебіг і ступінь компенсації пацієнтів $з$ ГТ автоімунного генезу.

Результати наших досліджень свідчать, що необхідно проводити скринінг дефіциту вітаміну D та систематичний моніторинг йодної забезпеченості у всіх пацієнтів із ГТ, особливо у жінок в пре- 
Огляди літератури, оригінальні дослідження, поглядн менопаузальному віці з Al3 щ3. Дефіцит вітаміну D корелює зі зниженням функції ЩЗ та тяжкістю ГТ, що визначає необхідність додаткового призначення вітаміну D всім пацієнтам із автоімунною патологією ЩЗ. Для адекватного йодного забезпечення жінкам, хворим на ГТ, необхідно проводити моніторинг надходження йоду в організм у вигляді йодованої солі та продуктів харчування з контрольним визначенням тиреоїдного гормонального статусу та концентрації йоду в організмі.

Висновки. 1. У 78,8 \% жінок пременопаузального віку з автоімунним ГТ визначається дефіцит вітаміну D, у 17,1 \% - нестача і у 4,1 \% нормальне забезпечення вітаміном D .

2. Результати визначення медіани йодурії у жінок пременопаузального віку з ГТ автоімунного генезу свідчать про недостатнє йодне забезпечення у 48,9 \% хворих (легкий дефіцит йоду у 26,7 \% і середнього ступеня тяжкості у 22,2 \%) та надмірне йодне навантаження у 8,9 \% хворих.

3. Встановлено, що 25(OH)D має достовірно сильну негативну кореляцію з АТПО та рівнем ТТГ і середню позитивну кореляцію із рівнями в з $_{3}$ BT. Дефіцит вітаміну D корелює зі зниженням функції щЗ та тяжкістю ГТ, що визначає необхідність додаткового призначення вітаміну D усім пацієнтам із автоімунною патологією ЩЗ.

4. У результаті кореляційного аналізу визначено позитивні взаємозв'язки середньої сили між рівнем медіани екскреції йоду та рівнями ТТГ, АТПО. Для контролю йодного статусу жінкам із автоімунною патологією ЩЗ необхідно проводити моніторинг функції ЩЗ та концентрації йоду в організмі.

\section{ЛІТЕРАТУРА}

1. Андрюков Б. Г. Избыток йода в организме - экологический фактор риска развития аутоиммунных заболеваний щитовидной железы? / Б. Г. Андрюков, Т. А. Гвозденко, Н. Б. Демьяненко // Медицинская экология. 2015. - № 2 (60). - С. 6-16.

2. Скрипник Н. В. Динаміка захворюваності й поширеності вузлових утворень щитоподібної залози в Україні та на Прикарпатті / Н. В. Скрипник, О. В. Марусин // Практикуючий лікар. - 2017. - № 2 (6). - С. 26-29.

3. Роль мікроелементів у етіології йододефіцитних захворювань / В. Н. Корзун, Ю. С. Котикович, І. Ю. Антонюк [та ін.] // Проблеми харчування. - 2011. - № 3 (4). C. 29-35.

4. Farebrother J. Excess iodine intake: sources, assessment, and effects on thyroid function / J. Farebrother, M. B. Zimmermann, M. Andersson // Ann. N.Y. Acad. Sci. 2019. - Vol. 1446 (1). - P. 44-65. DOI: 10.1111/nyas.14041.

5. Charoenngam N. The ongoing D-lemma of vitamin D supplementation for nonskeletal health and bone health / N. Charoenngam, A. Shirvani, M. F. Holick // Curr. Opin. Endocrinol., Diabet. Obes. - 2019. - No. 26 (6). - P. 301-305. DOI: 10.1097/MED.0000000000000508.

6. Vitamin D3-mediated resistance to a multiple sclerosis model disease depends on myeloid cell 1,25-dihydroxyvitamin D3 synthesis and correlates with increased CD4+ T cell CTLA-4 expression / J. A. Spanier, F. E. Nashold, C. D. Nelson [et al.] // J. Neuroimmunol. - 2020. - № 338. P. 577105. DOI: 10.1016/j.jneuroim.2019.577105.

7. Vitamin $D$, autoimmune disease and rheumatoid arthritis / S. R. Harrison, D. Li, L. E. Jeffery [et al.] // Calcif. Tissue Int. - 2020. - № 106 (1). - P. 58-75. DOI:10.1007/ s00223-019-00577-2.

8. Паньків І. В. Взаємозв'язок дефіциту вітаміну Д та автоімунної патології щитоподібної залози / І. В. Паньків // Буковинський медичний вісник. - 2015. - № 4 (76). P. 132-136.

9. Low levels of serum vitamin D3 are associated with autoimmune thyroid disease in pre-menopausal women /
Y. M. Choi, W. G. Kim, T. Y. Kim [et al.] // Thyroid. - 2014. No. 24 (4). - P. 655-661. DOI:10.1089/thy.2013.0460.

10. Поворознюк В. В. Взаємозв'язок дефіциту вітаміну D зі зниженою функцією щитоподібної залози / B. В. Поворознюк, І. В. Паньків // Клін. ендокринол. та ендокр. хір. - 2014. - № 3 (48). - С. 12-16.

11. Krysiak R. The Effect of Vitamin D on thyroid autoimmunity in levothyroxine-treated women with Hashimoto's thyroiditis and normal Vitamin D Status / R. Krysiak, W. Szkróbka, B. Okopień // Exp. Clin. Endocrinol. Diabetes. - 2017. No. 125 (4). - P. 229-233. DOI: 10.1055/s-0042-123038.

12. Поворознюк В. В. Вміст вітаміну D у хворих на автоімунний тиреоїдит із зниженою функцією щитоподібної залози / В. В. Поворознюк, І. В. Паньків // Міжнар. ендокринол. журн. - 2014. - № 5. - С. 27-30.

13. The association between low Vitamin $D$ status and autoimmune thyroid disease in Korean premenopausal women: The 6th Korea national health and nutrition examination survey 2013-2014 / C. Y. Kim, Y. J. Lee, J. H. Choi [et al.] // Korean J. Fam. Med. - 2019. - No. 40 (5). - P. 323-328. DOI:10.4082/kjfm.18.0075.

14. Kim D. Low vitamin D status is associated with hypothyroid hashimoto's thyroiditis / D. Kim // Hormones. 2016. - No. 15 (3). - P. 385-393. DOI:10.14310/ horm.2002.1681.

15. Кравченко В. І. Біологічна роль йоду та йодна недостатність як патогенетичний фактор виникнення тиреоїдної патології у вагітних та ії профілактика / В.І.Кравченко, Б. К. Медведєв // Міжнар. ендокринол. журн. - 2018. - № 2 (14). - С. 111-118.

16. Biomarkers of nutrition for development-iodine review / F. Rohner, M. Zimmermann, P. Jooste [et al.] // J. Nutr. - 2014. - No. 144. - P. 1322S-1342S. DOI: 10.3945/ jn.113.181974.

17. lodine excess as an environmental risk factor for autoimmune thyroid disease / Y. Luo, A. Kawashima, Y. Ishido [et al.] // Int. J. Mol. Sci. - 2014. - No. 15 (7). - P. 1289512912. DOI:10.3390/ijms150712895. 
Огляди літератури, оригінальні дослідження, поглядн на

18. An epidemiological survey of the prevalence of thyroid diseases in mild iodine deficiency city after salt iodization / N. C. Peng, L. X. Shi, Q. Zhang [et al.] // Zhonghua Nei Ke Za Zhi. - 2013. - No. 52. - P. 16-20.

19. Changes of the spectrum on thyroid disease after the 10-year implementation of universal salt iodization in лему, випадок з практики, короткі повідомлення Guangxi Zhuang Autonomous Region / J. Y. Zhang, S. M. Li, J. L. Leng [et al.] // Zhonghua Liu Xing Bing Xue Za Zhi. 2013. - No. 34. - P. 970-974.

20. Duntas L. H. The role of iodine and selenium in autoimmune thyroiditis / L. H. Duntas // Horm. Metab. Res. 2015.-No. 47 (10).-P.721-726.DOI:10.1055/s-0035-1559631.

\section{REFERENCES}

1. Andriukov, B.H. (2015). Izbytok yoda v organizme - ekologicheskyy faktor riska razvitiya autoimunnykh zabolevaniy shchytovidnoy zhelezy? [Is an excess of iodine in the body an environmental risk factor for the development of autoimmune thyroid diseases?]. Medytsynskaya ekologiya - Medical Ecology, 2 (60), 6-16 [in Russian].

2. Skrypnyk, N.V. (2017). Dynamika zakhvoriuvanosti i poshyrenosti vuzlovykh utvoren shchytopodibnoi zalozuy v Ukraini ta na Prykarpatti [Dynamics of morbidity and prevalence of thyroid nodules in Ukraine and in the Carpathians]. Praktykuiuchyi likar - Practitioner, 2 (6), 26-29 [in Ukrainian].

3. Korzun, V.N. (2011). Rol mikroelementiv u etiolohii yododefitsytnykh zakhvoriuvan [The role of trace elements in the etiology of iodine deficiency diseases]. Problemy kharchuvannia - Nutrition Problems, 3 (4), 29-35 [in Ukrainian].

4. Farebrother, J., Zimmermann, M.B., \& Andersson, M. (2019). Excess iodine intake: sources, assessment, and effects on thyroid function. Ann. N.Y. Acad. Sci., 1446 (1), 44-65. DOI: 10.1111/nyas.14041.

5. Charoenngam, N., Shirvani, A., \& Holick, M.F. (2019). The ongoing D-lemma of Vitamin D supplementation for nonskeletal health and bone health. Curr. Opin. Endocrinol., Diabet. Obes., 26 (6), 301-305. DOI: 10.1097/ MED.0000000000000508.

6. Spanier, J.A., Nashold, F.E., Nelson, C.D., Praska, C.E., \& Hayes, C.E. (2020). Vitamin D3-mediated resistance to a multiple sclerosis model disease depends on myeloid cell 1,25-dihydroxyvitamin D3 synthesis and correlates with increased $C D 4+T$ cell CTLA-4 expression. J. Neuroimmunol., 338, 577105. DOI:10.1016/j.jneuroim.2019.577105.

7. Harrison, S.R., Li, D., Jeffery, L.E., Raza, K., \& Hewison, M. (2020). Vitamin D, autoimmune disease and rheumatoid arthritis. Calcif. Tissue Int., 106 (1), 58-75. DOI:10.1007/s00223-019-00577-2.

8. Pankiv, I.V. (2015). Vzaiemozviazok defitsytu vitaminu $D$ ta avtoimunnoi patolohii shchytopodibnoi zalozy [The relationship between vitamin D deficiency and autoimmune pathology of the thyroid gland]. Bukovynskyi medychnyi visnyk - Bukovynian Medical Bulletin, 4 (76), 132136 [in Ukrainian].

9. Choi, Y.M., Kim, W.G., Kim, T.Y., Bae, S.J., Kim, H.-K., Jang, E.K., ..., \& Kim, W.B. (2014). Low levels of serum vitamin D3 are associated with autoimmune thyroid disease in pre-menopausal women. Thyroid, 24 (4), 655-661. DOI:10.1089/thy.2013.0460.

10. Povorozniuk, V.V., \& Pankiv, I.V. (2014). Vzaiemozviazok defitsytu vitaminu $D$ zi znyzhenoiu funktsiieiu shchytopodibnoi zalozy [The relationship between vitamin D deficiency and reduced thyroid function]. Klin. Endo- krynol. ta Endokr. Khir. - Clin. Endocrinol. Endocr. Surg., 3 (48), 12-16 [in Ukrainian].

11. Krysiak, R., Szkróbka, W., \& Okopień, B. (2017). The effect of vitamin D on thyroid autoimmunity in levothyroxine-treated women with Hashimoto's thyroiditis and normal vitamin D status. Exp. Clin. Endocrinol. Diabetes.,125 (4), 229-233. DOI:10.1055/s-0042-123038.

12. Povorozniuk, V.V., \& Pankiv, I.V. (2014). Vmist vitaminu $D$ u khvorykh na avtoimunnyi tyreoidyt iz znyzhenoiu funktsiieiu shchytopodibnoi zalozy [Vitamin D content in patients with autoimmune thyroiditis with hypothyroidism]. Mizhnar. Endokrynol. Zhurn. - Int. J. Endocrinol., 5, 27-30 [in Ukrainian].

13. Kim, C.-Y., Lee, Y.J., Choi, J.-H., Lee, S.Y., Lee, H.Y., Jeong, D.H., \& Choi, Y.J. (2019). The association between low Vitamin D status and autoimmune thyroid disease in Korean premenopausal women: The 6th Korea national health and nutrition examination survey 2013-20. Korean. J. Fam. Med., 40 (5), 323-328. DOI:10.4082/kjfm.18.0075.

14. Kim, D. (2016). Low vitamin D status is associated with hypothyroid hashimoto's thyroiditis. Hormones, 15 (3), 385-393. DOI:10.14310/horm.2002.1681.

15. Kravchenko, V.I., \& Medvediev B.K. (2018). Biolohichna rol yodu ta yodna nedostatnist yak patohenetychnyi faktor vynyknennia tyreoidnoi patolohii u vahitnykh ta yii profilaktyka [Biological role of iodine and iodine deficiency as a pathogenetic factor in the occurrence of thyroid pathology in pregnant women and its prevention]. Mizhnar. Endokrynol. Zhurn. - Int. J. Endocrinol., 2 (14), 111118 [in Ukrainian].

16. Rohner, F., Zimmermann, M., Jooste, P., Pandav, C., Caldwell, K., Raghavan, R., \& Raiten, D.J. (2014). Biomarkers of nutrition for development-iodine review. J. Nutr., 144, 1322S-1342S. DOI: 10.3945/jn.113.181974.

17. Luo, Y., Kawashima, A., Ishido, Y., Yoshihara, A., Oda, K., Hiroi, N., ..., \& Suzuki, K. (2014). lodine excess as an environmental risk factor for autoimmune thyroid disease. Int. J. Mol. Sci., 15 (7), 12895-12912. DOI: 10.3390/ ijms150712895.

18. Peng, N.-Ch., Shi, L.-X., Zhang, Q., Xu, S.-J., Li, H., Zhang, M., ... \& Liu, L. (2013). An epidemiological survey of the prevalence of thyroid diseases in mild iodine deficiency city after salt iodization. Zhonghua Nei Ke Za Zhi., 52, 16-20.

19. Zhang, J.-Y., Li, S.-M., Leng, J.-L., Chen, Y.-J., Pu, J., Li, J.-M., ..., \& He, H.-Y. (2013). Changes of the spectrum on thyroid disease after the 10 -year implementation of universal salt iodization in Guangxi Zhuang autonomous region. Zhonghua Liu Xing Bing Xue Za Zhi., 34, 970-974.

20. Duntas, L.H. (2015) The role of iodine and selenium in autoimmune thyroiditis. Horm. Metab. Res., 47 (10), 721-726. DOI:10.1055/s-0035-1559631. 
Огляди літератури, оригінальні дослідження, погляд на проблему, випадок з практики, короткі повідомлення

\title{
ОЦЕНКА УРОВНЯ ВИТАМИНА D И ЙОДНОГО СТАТУСА У ЖЕНЩИН ПРЕМЕНОПАУЗАЛЬНОГО ВОЗРАСТА С АУТОИММУННЫМ ЗАБОЛЕВАНИЕМ ЩИТОВИДНОЙ ЖЕЛЕЗЫ
}

๑О. О. Чукур, Н. В. Пасечко, А. О. Боб

Тернопольский национальный медицинский университет имени И. Я. Горбачевского МОЗ Украины

PEзЮМЕ. У женщин пременопаузального возраста с гипотиреозом аутоиммунного генеза наблюдались дефицит витамина D и недостаточное йодное обеспечение.

Цель - определить уровень обеспеченности витамином 25(OH)D и провести оценку медианы йодурии у женщин пременопаузального возраста с аутоиммунным гипотиреозом.

Материал и методы. Обследовано 146 женщин пременопаузального возраста с гипотиреозом на фоне аутоиммунного тиреоидита. Для оценки функционального состояния щитовидной железы определяли уровень тиреотропного гормона, свободного тироксина, свободного трийодтиронина и уровней антител к тиреопероксидазе и тиреоглобулину. Определяли уровень витамина D в сыворотке крови в осенне-зимний период и оценивали йодное обеспечение по концентрации йода в разовых порциях мочи.

Результаты. У 78,8 \% женщин пременопаузального возраста с аутоиммунным гипотиреозом определялся дефицит и у 17,1 \% недостаточность витамина D. Результаты определения медианы йодурии показали недостаточное йодное обеспечение у 48,9 \% больных (легкий дефицит йода у 26,7 \% и средней степени тяжести у 22,2 \%) и чрезмерные йодные нагрузки у 8,9 \% больных. Установлены достоверно сильные негативные корреляционные взаимосвязи между 25(ОН)D и уровнями антител к тиреопероксидазе и тиреотропного гормона и среднюю положительную корреляцию с уровнями свободного тироксина и свободного трийодтиронина (р<0,05). Корреляционный анализ определил положительные взаимосвязи средней силы между уровнем медианы экскреции йода и уровнями тиреотропного гормона и антител к тиреопероксидазе $(p<0,05)$.

Вывод. Дефицит витамина D коррелирует со снижением функции щитовидной железы и тяжестью гипотиреоза, что определяет необходимость дополнительного назначения витамина D всем женщинам пременопаузального возраста с аутоиммунным гипотиреозом. Для контроля йодного статуса женщин с гипотиреозом аутоиммунного генеза необходимо проводить мониторинг функции щитовидной железы и концентрации йода в организме.

КЛЮЧЕВЫЕ СЛОВА: щитовидная железа; гипотиреоз; аутоиммунный тиреоидит; постменопаузальный возраст; витамин D; йодурия; йододефицит.

\section{EVALUATION OF VITAMIN D LEVEL AND IODINE STATUS IN PREMENOPAUSAL WOMEN WITH AUTOIMMUNE THYROID DISEASE}

\author{
๑O. O. Chukur, N. V. Pasechko, A. O. Bob \\ I. Horbachevsky Ternopil National Medical University
}

SUMMARY. Vitamin D deficiency and insufficient iodine supply were observed in premenopausal women with hypothyroidism of autoimmune origin.

The aim - to determine the level of vitamin $25(\mathrm{OH}) \mathrm{D}_{3}$ and to assess the median ioduria in premenopausal women with autoimmune hypothyroidism.

Material and Methods. 146 premenopausal women with autoimmune hypothyroidism were examined. To assess the functional state of the thyroid gland, the level of thyroid-stimulating hormone, free thyroxine, free triiodothyronine and the level of antibodies to thyroperoxidase and antibodies to thyroglobulin were determined. Serum vitamin D levels were determined in the autumn-winter period and iodine supply was assessed by the concentration of iodine in single portions of urine.

Results and Discussion. $78.8 \%$ of premenopausal women with autoimmune hypothyroidism had deficiency of vitamin $D$ and $17.1 \%$ had insufficiency of vitamin $D$. The results of determining the median of ioduria showed insufficient iodine supply in $48.9 \%$ of patients (mild iodine deficiency in $26.7 \%$ and moderate severity in $22.2 \%$ ) and excessive iodine suply in $8.9 \%$ of patients. Significantly strong negative correlations were found between $25(\mathrm{OH}) \mathrm{D}$ and the level of antibody to thyroperoxidase and thyroid-stimulating hormone and a medium positive correlation with the level of free thyroxine and free triiodothyronine $(p<0.05)$. Correlation analysis revealed positive relationships of the mean strength between the level of median iodine excretion with the level of thyroid-stimulating hormone and the level of antibodies to thyroperoxidase $(p<0,05)$.

Conclusion. Vitamin D deficiency correlates with decreased thyroid function and the severity of hypothyroidism, which determines the need for additional prescription of vitamin D for all premenopausal women with autoimmune hypothyroidism. To control the iodine status of women with autoimmune hypothyroidism, it is necessary to monitor thyroid function and iodine concentration in the body.

KEY WORDS: thyroid; hypothyroidism; autoimmune thyroiditis; postmenopausal age; vitamin D; ioduria; iodine deficiency.

Отримано 12.10. 2020 